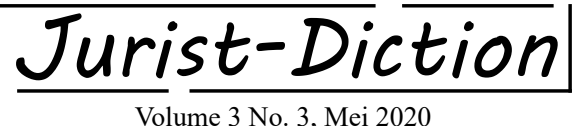

\section{Kesalahan Penyusunan Harga Perkiraan Sendiri (HPS) Dalam Pengadaan Barang / Jasa Pemerintah Yang Berimplikasi Tindak Pidana}

\author{
Syahna Nabila Rachmania \\ syahna.nabila.rachmania-2016@fh.unair.ac.id \\ Universitas Airlangga
}

\begin{abstract}
How to cite:
Syahna Nabila Rachmania, 'Kesalahan Penyusunan Harga Perkiraan Sendiri (HPS) Dalam Pengadaan Barang / Jasa Pemerintah Yang Berimplikasi Tindak Pidana' (2020) Vol. 3 No. 3 Jurist-Diction.

Histori artikel:

Submit 1 April 2020; Diterima 22 April 2020; Diterbitkan 1 Mei 2020.

DOI:

10.20473/jd.v3i3.18641
\end{abstract}

\begin{abstract}
Abstrak
Pengadaan Barang/Jasa merupakan salah satu kegiatan yang penting dalam berbagai aspek kehidupan. Dari tahapan Pengadaan Barang / Jasa terdapat salah satu Tahapan yang disebut Tahap Persiapan. Salah satu kegiatan yang dilakukan dalam tahapan Persiapan Pengadaan Barang / Jasa adalah penyusunan Harga Perkiraan Sendiri (HPS). Penyusunan Harga Perkiraan Sendiri (HPS) merupakan salah satu langkah strategis dalam pengadaan barang/jasa adalah yang digunakan sebagai batas harga tertinggi agar penyedia dapat melakukan penawaran. Dokumen HPS merupakan dokumen yang disusun sebelum melakukan pembelanjaan anggaran yang berasal dari Anggaran Pendapatan dan Belanja Negara (APBN) dan Anggaran Pendapatan dan Belanja Daerah (APBD).Kesalahan dalam penyusunan HPS acap kali diidentikan sebagai celah untuk melakukan tindak pidana korupsi dengan cara penggelembungan harga atau mark up terhadap HPS. Salah satu pola kesalahan dalam penyusunan HPS dapat terdeteksi dari unit-price yang tidak realistis dan pembengkakan jumlah APBN/APBD. Namun kesalahan penyusunan HPS tidak selalu berimplikasi pada tindak pidana korupsi. Hal tersebut akan berakibat pada perbedaan pertanggungjawaban dari pihak yang melakukan kesalahan yang berkaitan dengan HPS dalam pengadaan barang/jasa.

Kata Kunci: Harga Perkiraan Sendiri (HPS); Tindak Pidana Korupsi; Pertanggungjawaban.
\end{abstract}

\section{Pendahuluan}

Indonesiamerupakansalahsatunegarayangsedanggencarmelakukanpembangunan nasional yang berkesinambungan dan terarah dalam bidang politik, ekonomi, hukum, sosial, dan budaya menuju tercapainya kesejahteraan masyarakat Indonesia. Salah satu kiat yang dilakukan untuk meningkatkan kesejahteraan masyarakat adalah melaksanakan pembangunan infrastruktur guna menyediakan pelayanan publik yang berkualitas. Untuk melakukan pembangunan infrastruktur maka diperlukan pos anggaran yang dialokasikan khusus agar dapat melakukan pembelanjaan keuangan negara. 
Pembelanjaan keuangan negara untuk pembangunan tersebut berasal dari alokasi anggaran pengeluaran untuk belanja barang dan jasa menggunakan dana yang berasal dari Anggaran Pendapatan dan Belanja Negara (APBN) dan Anggaran Pendapatan dan Belanja Daerah (APBD). Namun, anggaran yang semestinya bisa lebih banyak dimanfaatkan untuk membiayai pembangunan lainnya, justru terkuras di dalam kegiatan pengadaan barang/ jasa yang tidak efektif dan efisien. Hal ini karena ada pihak-pihak tertentu yang memiliki paradigma berpikir hanya untuk mencari keuntungan pribadi, dan mengenyampingkan kepentingan publik. ${ }^{1}$ Oleh karena itu, agar penggunaan Anggaran Pendapatan dan Belanja Negara (APBN) dan Anggaran Pendapatan dan Belanja Daerah (APBD) dapat digunakan secara efektif dan dapat dipertanggungjawabkan maka pembelanjaan keuangan negara untuk pembangunan tersebut dilaksanakan melalui proses Pengadaan dengan berpedoman pada Peraturan Perundang-undangan yang berlaku terkait Pengadaan Barang/Jasa Pemerintah.

Pengadaan Barang/Jasa Pemerintah adalah kegiatan Pengadaan Barang/Jasa oleh Kementerian/Lembaga/Perangkat Daerah yang prosesnya sejak identifikasi kebutuhan, sampai dengan serah terima hasil pekerjaan dan dilaksanakan berdasarkan prinsip dasar yaitu prinsip efisien, efektif, transparan, terbuka, bersaing, adil dan akuntabel. ${ }^{2}$ Pengadaan Barang/Jasa merupakan kegiatan yang dilakukan untuk mendapatkan barang, jasa konsultasi, jasa lainnya dan pekerjaan konstruksi. Pengadaan Barang/Jasa Pemerintah terdiri dari beberapa tahapan, yaitu Tahap Perencanaan, Tahap Persiapan, Tahap Pelaksanaan dan Tahap Serah Terima Pekerjaan.

Dari tahapan Pengadaan Barang / Jasa tersebut diatas disebutkan salah satunya Tahap Persiapan. Dalam tahapan Persiapan Pengadaan Barang / Jasa tersebut disebutkan bahwa salah satu kegiatan yang dilakukan adalah penyusunan Harga Perkiraan Sendiri (HPS). Harga Perkiaan Sendiri yang untuk selanjutnya disebut

\footnotetext{
1 Senator Nur Bahagia, 'Sistem pengadaan publik dan cakupannya' (2011) 1 (1) Jurnal Pengadaan Senarai Pengadaan Barang / Jasa Pemerintah.[5].

2 Randy Kristovandy Tamesia, 'Studi Efektivitas Pengadaan Barang dan Jasa Pemerintah Secara Tradisional dan Elektronik’ (2015) 2 (12) Jurnal Teknik Sipil.[136-145].
} 
dengan HPS adalah perkiraan harga barang/jasa yang ditetapkan oleh Pejabat Pembuat Komitmen yang untuk selanjutnya disebut dengan PPK, yang berfungsi sebagai intrumen untuk menilai kewajaran harga penawaran dan untuk menetapkan besaran tambahan nilai jaminan pelaksanaan bagi penawaran yang dinilai terlalu sendah tapi tidak dapat dijadikan dasar untuk menggugurkan penawaran. ${ }^{3}$

Dokumen HPS merupakan dokumen yang disusun sebelum melakukan pembelanjaan anggaran yang berasal dari Anggaran Pendapatan dan Belanja Negara (APBN) dan Anggaran Pendapatan dan Belanja Daerah (APBD). Dokumen tersebut menjadi dasar untuk menetapkan batas tertinggi penawaran yang sah, dan sebagai dasar untuk menetapkan besaran nilai Jaminan Pelaksanaan. Sebelum itu, untuk dapat menyusun HPS maka disusun terlebih dahulu dokumen Spesifikasi Teknis. Spesifikasi teknis merupakan deskripsi detail tentang persyaratan kinerja barang, jasa, atau pekerjaan dalam memenuhi kebutuhan yang telah ditetapkan (performance) atau deskripsi detai mengenai kualitas bahan, metode dan standar kulitas barang, jasa atau perkerjaan yang harus diberikan kepada penyedia (conformance) $)^{4}$

Dokumen Spesifikasi Teknis dan Harga Perkiraan Sendiri (HPS) merupakan salah satu dokumen yang menjadi acuan investigasi apakah ada tindak pidana dalam suatu Pengadaan Barang / Jasa. Walaupun menjadi acuan investigasi, tetapi dokumen ini tidak dapat digunakan sebagai dasar menghitung kerugian negara melainkan digunakan untuk menilai kewajaran dari harga penawaran yang diajukan. Berdasarkan Investigasi dari Indonesia Corruption Watch celah oknum melakukan Tindak Pidana Korupsi adalah melalui pengadaan barang dan jasa. Hampir 80\% kasus yang ditangani oleh Komisi Pemberantasan Korupsi (KPK) berasal dari sektor Pengadaan Barang dan jasa. ${ }^{5}$ Indonesia Procurement Watch (IPW) mengidentifikasi

\footnotetext{
3 Amiruddin, Korupsi Dalam Pengadaan Barang dan Jasa (Genta Publishing 2010).[53].

4 Samsul Ramli, Bacaan Wajib Mengatasi Aneka Masalah Teknis Pengadaan Barang dan Jasa (Transmedia pustaka 2014).[294].

5 Ambranie Nadia Kemala Movanita, "Ini celah kecurangan pengadaan barang dan jasa yang bertonse korupsi”, Kompas.com (online), 28 September 2017. https://nasional.kompas.com/ $\mathrm{read} / 2017 / 09 / 28 / 19204361 /$ ini-celah-kecurangan-pengadaan-barang-dan-jasa-yang-berpotensi-korupsi?page=all [1].
} 
faktor penyebab terjadinya korupsi dalam pengadaan barang dan jasa pemerintah, pertama, lemahnya kerangka hukum dan kelembagaan; kedua, lemahnya kapasitas pengelola pengadaan barang dan jasa pemerintah; dan ketiga, lemahnya kepatuhan terhadap peraturan, pengawasan dan penegakannya. ${ }^{6}$

Secara umum dalam proses Pengadaan Barang / Jasa, suatu tindakan dapat diindikasikan masuk dalam ranah Tindak Pidana Korupsi apabila memenuhi unsur-unsur pidana dalam pengadaan barang dan jasa, yaitu apabila terdapat, penyalahgunaan wewenang, ada pihak yang memperkaya diri sendiri, orang lain atau korporasi, merugikan keuangan negara atau perekonomian negara dan/atau suap dan gratifikasi. Istilah corruption dalam Black's Law Disctionary didefinisikan:

(Henry Campbell Black; 1995: 277.)

"...a vicious and fraudulent intention to evade the prohibitions of the law. The act of an official or fiduciary person who unlawfully and wrongfully uses his station or character to procure some benefit for himself or for another person, contrary to duty and the rights of others. ". ${ }^{7}$

Penyusunan HPS akan menjadi salah satu penentu dalam dilakukannya proses penawaran oleh Penyedia Barang/Jasa. Penyusunan HPS yang terlalu tinggi atau terlalu rendah akan menibulkan akibat yang berbeda. Apabila HPS disusun dengan harga yang lebih mahal dari harga wajar maka dapat menimbulkan potensi kerugian negara berupa Mark Up dan dapat dianggap telah terjadi adanya persekongkolan antara pengelola pengadaan dan penyedia Barang/Jasa. Namun apabila HPS ditetapkan lebih rendah dari harga wajar maka dapat mengakibatnya potensi gagalnya pelaksanaan Tender karena apabila harga yang ditentukan lebih rendah, tidak akan ada penyedia Barang/Jasa yang akan mengikuti Pengadaan.

Kurangnya batasan yang tegas bagi Pejabat Pembuat Komitmen (PPK) dalam penyusunan Spesifikasi Teknis maupun HPS menyebabkan semakin luas indikasi Mark Up yang tentunya berimplikasi terhadaap dugaan Tindak Pidana Korupsi sebagai aspek di bidang pidana maupun aspek bidang hukum lain seperti

\footnotetext{
6 Amiruddin, Op.Cit.[13].

7 Black, Henry Campbell. 1995. Black's Law Dictionary. U.S: West Publishing. Co.
} 
administrasi. Oleh karena itu penyusunan Spesifikasi Teknis dan Harga Perkiraan Sendiri (HPS) harus mampu menghasilkan kualitas, kuantitas, harga barang dan jasa yang tepat sehingga dokumen Spesifikasi Teknis dan Harga Perkiraan Sendiri (HPS) tersebut harus dapat dipertanggungjawabkan.

Walaupun demikian, tidak serta merta kesalahan dalam penyusunan Harga Perkiraan Sendiri merupakan Tindak Pidana Korupsi. Risiko hukum dalam pengadaan barang/ jasa pemerintah dapat diidentifikasi dengan tiga sistem hukum, yaitu hukum administrasi negara, hukum perdata, dan hukum pidana dengan pertanggungjawaban yang berbeda di masing-masing bidang hukum. Dari sudut pandang hukum pidana, kegiatan Pengadaan Barang / Jasa ini sering kali digunakan sebagai instrumen untuk melakukan praktik Tindak Pidana Korupsi.

\section{Metode Penelitian}

Penelitian ini merupakan penelitian dogmatika hukum. Metode Pendekatan yang digunakan dalam penelitian ini adalah pendekatan perundang-undangan (statute approach), pendekatan konseptual (Conceptual Approach) dan Pendekatan Kasus (Case Approach) untuk mengkaji permasalahan hukum yang ada. Sumber yang digunakan dalam penelitian ini berdasarkan kajian kepustakaan terhadap peraturan perundang-undangan, buku-buku, makalah, jurnal yang berkaitan dengan Tindak Pidana Korupsi dan Pengadaan Barang/Jasa.

\section{Proses Pengadaan Barang/Jasa}

Pengadaan Barang/Jasa Pemerintah merupakan mekanisme belanja pemerintah yang memegang peranan penting dalam pemanfaatan anggaran negara. ${ }^{8}$ Pengadaan Barang/Jasa merupakan kegiatan pembiayaannya berasal dari Anggaran Pendapatan Belanja Negara (APBN) dan Anggaran Pendapatan Belanja Daerah (APBD) yang dilakukan oleh Kementrian, Lembaga dan perangkat Daerah.

\footnotetext{
8 A Edwin Parawangsyah, Analisis Hukum Tindak Pidana Korupsi Pada Bidang Pengadaan Barang/Jasa Konstruksi (Studi Putusan Nomor 74/Pid.Sus/2014/Pn.Mks), Fakultas Hukum Universitas Hassanudin, Makassar, 2017.[3]
} 
Untuk dapat melaksanakan kegiatan Pengadaan Barang/Jasa maka perlu untuk dilakukan pemilihan guna mendapatkan penyedia barang, Pekerjaan Konstruksi, Jasa konsultansi dan jasa lainnya dengan metode tertentu seperti tender, seleksi, seleksi internasional, penunjukan langsung dan pengadaan langsung. Pengadaan Barang/Jasa terdiri dilaksanakan beberapa pihak yang memiliki jabatan untuk melaksanakan Pengadaan, beberapa diantaranya yaitu PA, KPA, PPK, UKPBJ, Penyedia, APIP, Pokja Pemilihan, Pejabat Pengadaan, PjPHP, Agen Pengadaan. Agar Pengadaan Barang/Jasa dapat terlaksana dengan baik maka terdapat beberapa pihak yang memiliki tugas dan kewenangan yang berbeda satu sama lain. Terkait penyusunan HPS berdasarkan Peratura Presiden Nomor 16 Tahun 2018 tentang Pengadaan Barang/Jasa Pemerintah yang memiliki kewenangan untuk menyusun HPS adalah PPK.

Proses Pengadaan Barang/Jasa pada umumnya dapat dilakukan melalui 2 cara yaitu melalui Swakelola dan melalui Penyedia. Yang dimaksud dengan Pengadaan Barang/Jasa melalui Swakelola adalah cara untuk mendapatkan barang/jasa yang dikerjakan sendiri oleh Kementrian, Lembaga, Perangkat Daerah maupun K/L/PD lain, serta organisasi kemasyarakatan atau kelompok masyarakat.

Selain melalui Swakelola, cara lain untuk melakukan Pengadaan Barang/ Jasa adalah melalui Penyedia. Yang dimaksud dengan Pengadaan Barang/Jasa melalui Penyedia adalah cara untuk memperoleh barang/jasa yang disediakan oleh pelaku usaha, yaitu perorangan atau badan usaha yang berbentuk badan hukum maupun Non-badan hukum yang didirikan dan berkedudukan di Indonesia untuk melaksanakan kegiatan usaha tertentu.

Dalam Pengadaan Barang/Jasa terdapat beberapa tahapan yang harus dilalui yaitu Tahap Perencanaan, Tahap Persiapan, Tahap Pelaksanaan dan Tahap Serah Terima Pekerjaan. Tahap perencanaan dalam Pengadaan Barang / Jasa meliputi identifikasi kebutuhan, penetapan barang/jasa, cara, jadwal dan anggaran Pengadaan Barang / Jasa. Pengadaan Barang / Jasa yang bersumber dari dana APBN dan APBD dilaksanakan dengan cara swakelola atau Penyedia. Perencanaan pengadaan ini ditentukan oleh Pejabat pembuat Komitmen (PPK) dan kemudian akan ditetapkan oleh 
Pengguna Anggaran (PA) maupun Kuasa Penguna Anggaran (KPA). Dalam Tahap Persiapan Pengadaan, Pejabat pembuat Komitmen (PPK) menetapkan spesfirikasi teknis atau Kerangka Acuan Kerja (KAK), Harga perkiraan Sendiri (HPS), rancangan kontrak dan penetapan uang muka, jaminan uang muka, jaminan pelaksanaan, jaminan pemeliharaan, dan lain-lain. Dalam tahap ini Pejabat pembuat Komitmen (PPK) harus mengidentifikasi kategori barang / jasa yang hendak dilakukan pengadaan itu akan dilakukan melalui pengadaan langsung, E-purchasing, ataupun pengadaan khusus. Dalam tahap pelaksanaan Pejabat pembuat Komitmen (PPK) dan Pokja memilih penyedia sehingga dapat segera dituangkan dalam kontrak dan dalam pelaksanaan kontrak tersebut harus dilakukan sesuai dengan undang-undang. Dan tahapan yang terakhir yaitu Tahap Serah Terima Hasil Pekerjaan dilakukan serah terima pekerjaan yang telah selesai dilaksanakan sesuai dengan ketentuan yang ada di dalam kontrak. Dalam tahap ini dilakukan pemeriksaan barang/jasa yang akan diserahkan dan kemudian Pejabat Penandatanganan Kontrak dan penyedia menandatangani Berita Acara Serah Terima.

\section{Kedudukan Harga Perkiraan Sendiri (HPS)}

Harga Perkiraan Sendiri (HPS), adalah perkiraan harga barang/jasa dari hasil perhitungan volume tiap-tiap pekerjaan dikalikan dengan Harga Satuan masingmasing pekerjaan, ditambah dengan beban pajak, overhead cost dan keuntungan yang nilainya ditetapkan oleh Pejabat Pembuat Komitmen (PPK) yang berfungsi untuk melihat kewajaran harga penawaran. ${ }^{9}$ HPS disusun menyesuaikan dengan Pagu Anggaran yang ada. Berdasarkan Pagu Anggaran tersebut Pihak Pengguna Anggaran atau Kuasa Pengguna Anggaran menyusun dokumen Pelaksanaan Anggaran yang disebut dengan Daftar Isian Pelaksaaan Anggaran (DIPA) yang berfungsi sebagai dasar untuk dapat melakukan tindakan pengeluaran anggaran negara. ${ }^{10}$

\footnotetext{
9 Alfian Malik, 'Analisa Disparitas Harga Penawaran Terhadap Harga Perkiraan Sendiri Pada Pemilihan Penyedia Jasa Pekerjaan Jalan Dan Jembatan'(2013) 2 (5) Jurnal Aptek.[101]

${ }^{10}$ Bagian Pengadaan Barang/Jasa, "Daftar Isian Pelaksanaan Anggaran (DIPA): Jenis, Format dan Tata Cara Revisi DIPA”, https://bulelengkab.go.id, 31 Oktober 2018, dikunjungi pada tanggal 16 Oktober 2019
} 
Kedudukan dokumen HPS digunakan untuk menilai kewajaran dari harga penawaran dan harga satuan. HPS juga digunakan sebagai dasar untuk menetapkan batas tertinggi penawaran yang sah dan untuk menetapkan besaran nilai jaminan pelaksanaan bagi penawaran yang nilainya lebih rendah $80 \%$ dari nilai HPS. HPS dihitung dengan berdasaran data yang dapat dipertanggungjawabkan dengan memperhitungkan keuntungan dan biaya tidak langsung (overhead cost). Untuk mendapatkan total HPS maka diperlukan untuk menghitung Hasil Perhitungan HPS ditambah dengan Pajak Pertambahan Nilai (PPN). Dengan adanya HPS pengelola pengadaan barang / jasa memiliki dasar atau pedoman untuk menetapkan batas tertinggi penawaran dan besaran nilai jaminan. Namun adanya HPS ini tidak serta merta menjadi dasar untuk menilai ataupun menghitung besaran kerugian negara.

\section{Kesalahan dalam Penyusunan HPS}

a. Kesalahan Dalam Penyusunan HPS Yang Tidak berimplikasi Tindak Pidana Korupsi

Seorang pejabat dalam melaksanakan tugasnya harus bertanggungjawab, tanggungjawab seorang pejabat dibedakan antara tanggungjawab jabatan dan tanggungjawab pribadi ${ }^{11}$ Tanggung jawab jabatan adalah tanggung jawab menurut hukum yang dibebankan kepada negara/pemerintah atas kesalahan atau akibat dari tindakan jabatan. Dalam hukum administrasi parameter suatu tanggung jawab jabatan adalah asas legalitas (keabsahan) tindakan pemerintah yang tediri wewenang, prosedur dan subtansi.

Wewenang berdasarkan Pasal 1 angka 5 Undang-undang Nomor 30 Tahun 2014 Tentang Administrasi Pemerintahan adalah suatu hak yang dimiliki oleh pejabat untuk mengambil keputusan dalam penyelenggaraan pemerintahan. Cara untuk memperoleh wewenang dapat dilakukan dengan 3 cara yaitu atribusi, delegasi dan mandat. ${ }^{12}$ Salah satu wewenang Pejabat Pembuat Komitmen (PPK) dalam Pengadaan Barang/Jasa adalah menyusun dokumen HPS. Selain itu wewenang dari PPK sebagaimana diatur

${ }^{11}$ Philipus M. Hadjon, dkk, Hukum Administrasi dan Tindak Pidana Korupsi (Gadjah Mada University Press 2012).[16].

12 Loc Cit.[11-13]. 
dalam Pasal 11 Perpres 16 Tahun 2018 Tentang Pengadaan Barang / Jasa Pemerintah Tentang Pengadaan Barang/Jasa Pemerintah sebagai berikut:

a. menyusun perencanaan pengadaan;

b. menetapkan spesifikasi teknis/Kerangka Acuan Kerja (KAK);

c. menetapkan rancangan kontrak;

d. menetapkan HPS;

e. menetapkan besaran uang muka yang akan dibayarkan kepada Penyedia;

f. mengusulkan perubahan jadwal kegiatan;

g. menetapkan tim pendukung;

h. menetapkan tim atau tenaga ahli;

i. melaksanakanE-purchasing untuknilai paling sedikit di atas Rp200.000.000,00 (dua ratus juta rupiah);

j. menetapkan Surat Penunjukan Penyedia Barang/Jasa;

k. mengendalikan Kontrak;

1. melaporkan pelaksanaan dan penyelesaian kegiatan kepada PA/ KPA;

m. menyerahkan hasil pekerjaan pelaksanaan kegiatan kepada PA/ KPA dengan berita acara penyerahan;

n. menyimpan dan menjaga keutuhan seluruh dokumen pelaksanaan kegiatan

o. menilai kinerja Penyedia.

Atas wewenang tersebut badan atau pejabat pemerintahan dilarang untuk menyalahgunakan wewenangnya. Yang termasuk menyalahgunakan wewenang terdiri dari tindakan yang melampui wewenang seperti melampaui masa jabatan, batas wilayah berlakunya wewenang, dan tindakan yang bertentangan dengan peraturan perundang-undangan; tindakan yang yang mencampuradukan wewenang seperti melakukan tindakan diluar cakupan materi wewenang dan melakukan tindakan yang bertentangan dengan tujuan wewenang yang diberikan; tindakan yang sewenang-wenang seperti melakukan tindakan tanpa ada dasar kewenangan dan melakukan tindakan yang bertentangan dengan putusan pengadilan yang berkekuatan hukum tetap.

Selain wewenang, keabsahan tindakan pemerintahan dilihat dari Prosedurnya. Apabila kesalahan dalam hal prosedural maka tindakan atau keputusan pejabat dapat dapat dibatalkan, akibatnya tindakan atau keputusan pejabat tersebut tidak mengikat dan berakhir sejak saat dibatalkan. Yang dimaksud dengan kesalahan prosedur adalah kesalahan tatacara dalam menetapkan keputusan dengan cara yang tidak sesuai dengan tatacara yang diatur dalam peraturan perundang- 
undangan dan standar operasional prosedur. Prosedur secara umum yang dijadikan pedoman untuk menyusun HPS agar tidak terjadi kesalahan adalah dalam penyusunan dokumen tersebut Pejabat Pembuat Komitmen (PPK) harus disusun dengan informasi / data yang dapat dipertanggungjawabkan seperti melihat dari harga pasar setempat menjelang dilaksanakannya pemilihan penyedia, daftar harga yang telah di kurangi potongan harga, inflasi tahun sebelumnya, dan lainlain. Jumlah nilai dari HPS akan didapatkan dari hasil perhitungan HPS ditambah dengan Pajak Pertambahan Nilai (PPN).

Keabsahan tindakan pemerintahan yang terakhir dilihat dari subtansinya. Apabila terjadi kesalahan subtansi maka akibatnya tindakan atau keputusan pejabat dapat dapat dibatalkan. Yang dimaksud dengan kesalahan subtansi adalah apabila terdapat kondisi dimana ada ketidaksesuaian materi yang dikehendaki dengan rumusan dalam keputusan yang dibuat.

Tidak terpenuhinya syarat legalitas yang berupa prosedur, wewenang dan subtansi dalam proses pengadaan barang dan jasa akan mengakibatkan adanya tanggung jawab jabatan dari pengelola pengadaan barang / jasa. Perlu digaris bawahi adanya kerugian keuangan Negara dan adanya kesalahan wewenang, prosedur dan subtansi tidak serta merta menjadi indikasi dari adanya Tindak Pidana Korupsi. Untuk dapat membedakan kerugian Negara yang berakibat pada Tindak Pidana Korupsi dan diluar Tindak Pidana Korupsi, perlu dilihat bagaimana unsur kesengajaan dari pelaku.

Pada dasarnya kesalahan administrasi tidak dapat dipertanggungjawabkan secara pidana. Tetapi apabila dalam pelaksanaanya diketahui bahwa kesalahan administrasi yang dilakukan tersebut menimbulkan kerugian keuangan negara karena pejabat tersebut memiliki niat untuk memperkaya diri sendiri dengan menyalahgunakan wewenang, kesempatan maupun jabatan maka kesalahan administrasi tersebut merupakan penyebab terjadinya Tindak Pidana Korupsi sehingga dapat dipertangungjawabkan secara pidana. ${ }^{13}$

Mudjisantosa, Catatan Aspek Hukum Pengadaan dan Kerugian Negara (CV Primaprint 
b. Kesalahan Dalam Penyusunan HPS Yang berimplikasi Tindak Pidana Korupsi Tanggung jawab pidana adalah tanggung jawab menurut hukum yang dibebankan kepada seseorang atas kesalahan atau akibat dari perbuatannya secara pribadi. Pengertian ini tidak berbeda dengan pengertian tanggung jawab pribadi karena tanggung jawab pidana adalah tanggung jawab pribadi ${ }^{14}$ Parameter tanggung jawab hukum pidana adalah asas kesalahan, yaitu seseorang tidak akan dipidana apabila orang tersebut tidak melakukan kesalahan. Dan yang menjadi parameter utama dalam tanggung jawab pidana di pengadaan barang / jasa adalah melakukan penyalahgunaan wewenang yang hanya dapat dilakukan oleh pejabat dan perbuatan melawan hukum.

Dalam hal melakukan penyusunan HPS terdapat celah bagi para oknum pejabat untuk melakukan Tindak Pidana Korupsi dengan berbagai macam modus operandi. HPS yang disusun oleh Pejabat Pembuat Komitmen (PPK) digunakan sebagai alat ukur untuk menilai kewajaran harga penawaran dan untuk menetapkan besaran tambahan nilai jaminan. Namun dalam penyusunan HPS sering dilakukan penyimpangan yang dapat berimplikasi Tindak Pidana Korupsi. Beberapa diantaranya yaitu:

\section{Persekongkolan dan Mark Up Harga Perkiraan Sendiri (HPS)}

Faktor yang menjadi penyebab adanya tuduhan Tindak Pidana Korupsi dalam penyusunan HPS pengadaan barang/ jasa pemerintah yaitu karena ada moral hazard dari pengelola pengadaan. Moral Hazard merupakan perilaku tidak jujur demi untuk memenuhi keinginannya yang dipicu dari perilaku egoistis dan mementingkan diri sendiri. ${ }^{15}$ Dalam penyusunan HPS Pengadaan Barang/Jasa, moral hazard dari seorang pengelola pengadaan dapat mengakibatkan pejabat tersebut menghalalkan segala cara seperti melakukan Mark Up untuk mendapatkan harta dengan cara yang melawan hukum.

Penggelembungan anggaran atau biasa disebut dengan Mark $U p$ adalah suatu kondisi dimana harga ditentukan secara tidak wajar dengan cara menaikkan nya hingga

\footnotetext{
${ }^{14}$ Amiruddin, Op.Cit.[93].

${ }^{15}$ Nur Sayidah, 'Solusi Moral Dan Spiritual Atas Masalah Moral Hazard' (2017) Jurnal Ilmiah Akuntansi Dan Humanika.
} 
diatas rata-rata harga yang ada di pasaran pada umumnya. Penggelembungan Anggaran atau Mark Up ini mengakibatkan dampak negatif yaitu terjadinya pemborosan anggaran keuangan negara.

Contoh kasus Mark Up HPS yaitu, Pihak PPK dalam menyusun HPS dapat melakukan survey dari harga pasar. Pada saat PPK melakukan survey, ia menemukan suatu CV yang memberikan penawaran untuk melakukan persekongkolan harga Barang/ Jasa untuk dapat memenangkan pihak CV tersebut. Apabila PPK menyetujui untuk menyusun HPS per unit Barang/Jasa yang ia tetapkan lebih tinggi dari harga pasarnya dengan menyesuaikan harga yang ditawarkan CV tersebut dengan kesepakatan bahwa pihak PPK akan mendapatkan sejumlah uang atas tindakannya tersebut maka dapat diindikasikan PPK tersebut melakukan Tindak Pidana Korupsi. Dan apabila HPS yang ditetapkan tersebut belum termasuk biaya seperti PPN, install, ongkir, keuntungan dll maka dapat mengakibatkan pembengkakan anggaran yang sehingga terjadi kerugian keuangan negara yang lebih besar.

2. Spesifikasi Teknis dan HPS Tidak Disusun Oleh PPK

Berdasarkan Pasal 11 Ayat (1) huruf d Perpres 16 Tahun 2018 Tentang Pengadaan Barang / Jasa Pemerintah Tentang Pengadaan Barang/Jasa Pemerintah disebutkan bahwa salah satu tugas dari PPK adalah menentukan HPS namun terdapat beberapa kasus dimana HPS selain dalam Pengadaan Jasa Konstruksi tidak disusun oleh PPK melainkan disusun oleh rekanan yang nantinya akan menjadi calon pemenang dari pengadaan barang / jasa tersebut.

Indikasi yang dapat dilihat dalam praktik ini salah satunya adalah apabila Spesifikasi Teknis dan HPS yang ditentukan mengarah pada merk atau produk tertentu dengan alasan spekulasi teknis yang dibuat adalah yang terbaik sehingga sulit untuk disubstitusi (hanya satu produsen yang bisa memenuhi spekulasi teknis saat memasukkan penawaran) dan membuat ukuran yang tidak biasa (misalnya panjang $\mathrm{x}$ lebar dalam spekulasi teknis hanya satu produsen yang bisa memenuhi syarat. ${ }^{16}$ Walaupun penyusunan HPS yang dilakukan dengan menggunakan Owner Estimate

${ }^{16}$ Maslani Dan Siswanto, 'Audit Pengadaan Barang Jasa Mengenal Risiko Penyimpangan Untuk Pencegahan’ (2011) 1 Jurnal Pengadaan Senarai Pengadaan Barang / Jasa Pemerintah.[65]. 
bertujuan agar HPS lebih proporsional tetapi praktik ini merupakan praktik Kolusi yang akan cenderung memenangkan salah satu pihak.

3. Kurangnya Pengetahuan Informasi Dari PPK Terhadap Harga Spesifikasi Barang Untuk Menyusun HPS

Penawaran dinyatakan memenuhi persyaratan apabila menjamin pemenuhan spesifikasi teknis yang telah ditetapkan. ${ }^{17}$ Jenis pekerjaan dalam daftar kuantitas dan harga yang ditawarkan tidak boleh kurang kualitasnya dari ketentuan dokumen lelang. Dalam menyusun Sepsifikasi Teknis dilakukan degan cara menetapkan kebutuhan (performance) pengguna Barang/Jasa kemudian dari kebutuhan tersebut akan di sesuaikan dengan aspek teknisnya. Seorang PPK dalam menyusun Spesifikasi harus memperhatikan mutu Barang/Jasa.

Spesifikasi Barang/Jasa harus disesuaikan dengan kebutuhan dan pos anggaran yang telah disediakan. Oleh karena itu seorang Pejabat Pembuat Komitmen (PPK) harus memahami dengan baik produk yang ada di pasaran. Sehingga nantinya dari spesifikasi barang yang dibutuhkan tersbut dapat dituangkan dalam dokumen Spesifikasi Teknis yang detail dan cermat, dan agar barang dari hasil pengadaan tersebut sesuai dengan kebutuhan dengan standar yang tepat.

\section{Konsep Pertanggungjawaban Pidana}

Pertanggungjawaban pidana (criminal responsibility) adalah penegakan hukuman terhadap subjek hukum yang melakukan tindak pidana atau tindakan yang dilarang. Asas yang dianut dalam pertanggungjawaban pidana adalah asas geen straf zonder schuld;Actus non facit reum nisi mens sist rea, yaitu suatu perbuatan tidak akan dikenakan pidana apabila tidak ada kesalahan. Unsur-unsur pertanggungjawaban pidana yaitu: ${ }^{18}$

17 Dwi Sukarmei, Pengaruh Metode Evaluasi Penawaran Pengadaan Barang/Jasa Pemerintah Terhadap Hasil Pekerjaan Dengan Pendekatan Analytical Hierarchy Process ( Studi Kasus Di Pemerintah Kabupaten Temanggung ), Tesis , Program Magister Teknik Sipil Universitas Diponegoro, 2011.[16]

18 Amir Ilyas, Asas-Asas Hukum Pidana Memahami Tindak Pidana Dan Pertanggungjawaban Pidana Sebagai Syarat Pemidanaan (Rangkang Education Yogyakarta \& PuKAP-Indonesia 2012). [76]. 
a. Mampu bertanggung jawab;

b. Kesalahan;

c. Tidak ada alasan pemaaf dan alasan pembenar.

Kemapuan bertanggungjawab adalah kemampuan seseorang untuk dapat menerima akibat dari perbuatan yang telah dilakukan dilihat dari segi kesehatan mental maupun jasmani pelaku tindak pidana. ${ }^{19}$ Kemampuan bertanggungjawab dari seseorang dilihat dari bagaimana keadaan batin dari pelaku. Keadaan batin pelaku yang dianggap dapat bertanggung jawab adalah apabila pelaku terdapat gangguan pada kejiawaannya sebagaimana diatur dalam Pasal 44 KUHP. ${ }^{20}$

Implementasi hukum pidana berkaitan dengan pertanggunggjawaban pelaku berarti mengenakan sifat tercela dari perbuatan pidana pada orang itu sesuai dengan peran dan kapasitas pelaku atau kontribusinya dalam mewujudkan peristiwa pidana, sehingga patut dijatuhkan nestapa kepadanya. ${ }^{21}$ Pertanggungjawaban pidana kepada seseorang berkaitan erat dengan adanya unsur kesalahan dan sifat melawan hukum.

Melawan hukum merupakan salah satu unsur yang mutlak ada dalam suatu tindak pidana sebagaimana diatur dalam Pasal 1 KUHP terkait asal legalitas. Yang dimaksud dengan Asas legalitas yaitu asas yang menentukan bahwa tidak ada suatu perbuatan yang dapat dipidana kecuali atas perundang-undangan pidana yang sudah ada sebelum perbuatan itu dilakukan. ${ }^{22}$ Sifat melawan hukum dikaitkan dengan asas legalitas karena suatu perbuatan dikatakan melawan hukum karena perbuatan tersebut bertentangan dengan peraturan perundang-undangan yang berlaku sebagai hukum positif.

Terdapat 2 ajaran terkait Sifat melawan hukum yaitu sifat melawan hukum formil dan sifat melawan hukum materiil. Berdasarkan ajaran sifat melawan hukum formal, suatu perbuatan dikatakan melawan hukum apabila melanggar ketentuan yang ada di dalam peratungan perundang-undangan yang tertulis. Berdasarkan

\footnotetext{
${ }_{19}$ Tommy J. Bassang, 'Pertanggungjawaban Pelaku Tindak Pidana Deelneming' (2015) 5 (IV) Lex Crimen.[125].

${ }^{20}$ Moeljatno, Asas-asas Hukum Pidana (Rineka Cipta 2008).[178].

${ }^{21}$ Tommy J. Bassang, Op.Cit.[122].

${ }_{22}$ Salman Luthan, Luthan, Salman, 'Asas Dan Kriteria Kriminalisasi' (2006) 1 (16) Jurnal Hukum.[6].
} 
ajaran sifat melawan hukum materiil menyatakan bahwa suatu perbuatan dikatakan melawan hukum apabila terdapat seseorang yang melanggar hukum tidak tertulis seperti hukum kebiasaan, perbuatan yang melanggar hukum tidak tertulis dinilai berdasarkan kepatutannya oleh masyarakat. Selain sifat melawan hukum, untuk mengetahui bagaimana pertanggungjawaban seseorang terhadap perbuatan yang telah dilakukannya maka dilihat pula unsur kesalahan dari perbuatannya.

Kesalahan merupakan hal yang menyebabkan terjadinya tindak pidana karena terdapat seseorang yang melakukan perbuatan yang bersifat pelawan hukum sehingga yang bersangukutan harus mempertanggungjawabkan perbuatannya. Bentuk- bentuk kesalahan yaitu berupa kealpaan/kelalaian (culpa) dan kesengajaan (dolus). ${ }^{23}$ Bentuk kesengajaan terdiri dari Kesengajaan sebagai Maksud/Tujuan (opzet als oogmerk), Kesengajaan sebagai Kepastian (opzet bij zekerheidsbewuztzijn), dan Kesengajaan sebagai kemungkinan (opzet bij mogelijkheidsbewustzijn). Bentuk kelalaian terdiri dari kelalaian yang menimbulkan akibat dan kelalaian yang tidak menimbulkan akibat. ${ }^{24}$

Ancaman pidana diantara kesengajaan dan kealpaan terdapat perbedaan, ancaman pidana untuk kesengajaan lebih berat dibandingkan ancaman pidana untuk kelalaian. Namun pengenaan pidana terhadap pelaku tindak pidana dilihat dari segi kesalahannya harus didasarkan pada beberapa asas, salah satunya yaitu asas tiada pidana tanpa kesalahan.

Asas tiada pidana tanpa kesalahan merupakan asas yang penting dalam hukum pidana. Maksud dari asas ini adalah apabila seseorang tidak melakukan tindak pidana maka tidak perlu adanya suatu pertanggungjawaban pidana. Unsur-unsur kesalahan yaitu Adanya kemampuan bertanggungjawab dari pelaku; adanya hubungan batin antara si pelaku dengan perbuatannya, yakni berupa kesengajaan atau kealpaaan; dan tidak adanya alasan yang menghapus pidana atau tidak adanya alasan pemaaf. ${ }^{25}$

${ }^{23}$ Amir Ilyas, Op.Cit.[27].

24 Fitrahwaty Porwilah Syarif, Tinjauan Yurudis Kealpaan Seseorang Yang Menyebabkan Matinya Orang Lain Dalam Kecelakaan Lalu Lintas Di Polres Maros (Studi Kasus No. 136/ Pid.B/2012/Pn.Mrs), Skripsi, Program Studi Ilmu Hukum Universitas Hasanuddin, Makkasar, 2013. [18-20].

${ }_{25}$ Tommy J. Bassang, Op.Cit.[89]. 
Penghapus pidana dibagi menjadi 2 yaitu Alasan pembenar dan alasan pemaaf. Terdapat perbedaan konsep diantara keduanya, untuk alasan pembenar yang dihapuskan adalah perbuatan atau actus reus nya. Sedangkan alasan pemaaf yang dihapuskan adalah kesalahannya atau mensrea.

Penghapus pidana yang termasuk dalam alasan pemaaf yaitu apabila pelaku memenuhi yaitu tidak sehat kejiwaannya sesuai dengan Pasal 44 KUHP. Penghapus pidana yang termasuk dalam alasan pembenar yaitu terdapat dalam KUHP yaitu apabila terdapat daya paksa sebagaima diatur dalam Pasal 48 KUHP, pembelaan terpaksa sebagiama diatur dalam Pasal 49 KUHP, melaksanakan ketentuan Undangundang sebagimana diatur dalam Pasal 50 KUHP, dan Melaksanakan perintah jabatan yang diberikan oleh penguasa yang berwenang sebagaimana diatur dalam Pasal 51 KUHP.

\section{Pertanggungjawaban Terkait Penyusunan HPS Yang Berimplikasi Tindak}

\section{Pidana}

Penyusunan HPS merupakan salah satu tahapan dalam Pengadaan Barang/ Jasa. Kesalahan dalam penyusunan HPS dapat mengakibatkan indikasi Tindak Pidana Korupsi. Oleh karena itu HPS harus disusun berdasarkan prosedur yang tepat, yaitu penyusunan HPS harus dilaksanakan berdasarkan pada hasil perkiraan biaya atau Rencana Anggaran Biaya, Pagu Anggaran yang tercantum dalam DIPA/ DPA, dan berdasarkan hasil review perkiraan biaya/RAB termasuk didalamnya dihitung komponen keuntungan, biaya tidak langsung dan PPN namun dengan tidak memperhitungkan biaya tidak terduga, biaya lain-lain dan $\mathrm{PPh}$.

Pedoman dalam menyusun HPS yaitu, HPS harus disusun berdasarkan data/ informasi yang dapat dipertanggungjawabakan sebagaimana diatur dalam Peraturan Lembaga Nomor 9 Tahun 2018 yaitu :

a. harga pasar setempat yaitu harga barang/jasa di lokasi barang/jasa diproduksi/ diserahkan/dilaksanakan;

b. informasi biaya/harga satuan yang dipublikasikan secara resmi oleh Kementerian/ Lembaga/Pemerintah Daerah;

c. informasi biaya/harga satuan yang dipublikasikan secara resmi oleh asosiasi. Yang dimaksud dengan asosiasi adalah asosiasi profesi keahlian, baik yang 
berada di dalam negeri maupun di luar negeri;

d. Informasi biaya/harga satuan yang dipublikasikan termasuk pula sumber data dari situs web komunitas internasional yang menayangkan informasi biaya/ harga satuan profesi keahlian di luar negeri yang berlaku secara internasional termasuk dimana Pengadaan Barang/Jasa akan dilaksanakan;

e. daftar harga/biaya/tarif barang/jasa setelah dikurangi rabat/potongan harga (apabila ada) yang dikeluarkan oleh pabrikan/distributor/agen/pelaku usaha;

f. inflasi tahun sebelumnya, suku bunga pinjaman tahun berjalan dan/atau kurs tengah Bank Indonesia valuta asing terhadap Rupiah;

g. hasil perbandingan biaya/harga satuan barang/jasa sejenis dengan kontrak yang pernah atau sedang dilaksanakan;

h. perkiraan perhitungan biaya/harga satuan yang dilakukan oleh konsultan perencana (engineer's estimate);

i. informasi biaya/harga satuan barang/jasa di luar negeri untuk tender/seleksi internasional;

j. informasi lain yang dapat dipertanggungjawabkan.

Dalam melaksanakan tugasnya tidak menutup kemungkinan seorang pengelola pengadaan baik itu PPK, KPA, PA, Pokja Pemilihan, UKPBJ, PjPHP, PPHP, Agen Pengadaan, Penyedia Barang/Jasa dan lain-lain melakukan kesalahan. Kesalahan tersebut dapat berimplikasi pada bidang Hukum Pidana yaitu Tindak Pidana Korupsi.

Salah satu kesalahan yang dapat berimplikasi pada Tindak Pidana Korupsi adalah kesalahan dalam penyusunan HPS. Penyusunan HPS berdasarkan Peraturan Presiden Nomor 16 Tahun 2018 Tentang Pengadaan Barang/Jasa Pemerintah memang merupakan salah satu tugas dari PPK. Namun prakteknya HPS tidak hanya dapat disusun oleh PPK. Pihak lain seperti misalnya penyedia maupun PA/KPA juga dapat melakukan penyusunan HPS. Oleh karena itu tanggung jawab untuk kesalahan penyusunan HPS tidak serta atau mutlak menjadi kesalahan dari PPK dan untuk mengetahui siapa yang bertanggung jawab atas kesalahan penyusunan HPS dalam Pengadaan Barang/Jasa maka harus dilihat pula siapa yang melakukan penyusunan terhadap HPS tersebut.

Salah satu bentuk kesalahan dalam penyusunan HPS yaitu adanya Kemahalan harga. Kemahalan harga dalam penyusunan HPS dapat menimbulkan adanya Mark Up sebagai kemahalan harga yang dapat dikatakan menyalahi peraturan hukum yang berlaku, dan yang kemahalan harga yang menimbulkan overhead yang diperbolehkan oleh hukum. 
Mark up merupakan salah satu pola penyimpangan pada tahap persiapan dalam Pengadaan Barang/Jasa, Gejala ini dapat terdeteksi dari unit-price yang tidak realistis dan pembengkakan jumlah APBN/APBD. ${ }^{26}$ Suatu kemahalan harga dikatakan Mark Up ketika ada kesengajaan meninggikan nilai HPS agar mendapatkan keuntungan baik itu untuk diri sendiri maupun orang lain. Sedangkan suatu kemahalan harga di katakan overhead ketika ada keuntungan setelah memperhitungkan komponen biaya seperti PPN. Contoh suatu kemahalan harga dikatakan overhead adalah misalkan pada saat dilakukan diklat di hotel daerah pegunungan Tretes maka akan sulit mengakses toko terdekat untuk membeli Air Mineral. Oleh karena itu pihak panitia diklat membeli air mineral di hotel dengan harga Rp.5000,- / 1 botol padahal apabila dibeli di toko kelontong maka harga yang didapatkan adalah Rp.2.500,- / 1 botol dan apabila air mineral dibeli dari distributor maka akan mendapatkan harga Rp.2000,- / 1 botol. Oleh karena kemahalan harga dikarenakan panitia membeli air mineral di hotel maka tidak dapat dikatakan panitia diklat melakukan mark up, tetapi ada biaya overhead.

HPS harus disusun berdasarkan pada ketentuan yang berlaku diatas. Apabila HPS tidak disusun berdasarkan ketentuan tersebut maka dapat terjadi kesalahan dalam penyusunan HPS yang berimplikasi tindak pidana korupsi dan kesalahan yang tidak berimplikasi tindak pidana korupsi. Atas tindakannya tersebut pelaku harus mempertanggungjawabakan tindakannya sebagai tanggung jawab jabatan maupun tanggung jawab pribadi.

Penentuan utama adanya tanggung jawab jabatan dan tanggung jawab pribadi dilihat dari bagaimana kesengajaan dari pelaku. Apabila pelaku dalam menyusun HPS melakukan kesalahan prosedur, subtansi atau terkait wewenang maka ia haru mempertanggungjawabkantindakannya secarahukumadministrasi sebagaitanggung jawab jabatan. Namun apabila pelaku melakukan kesalahan prosedur subtansi atau terkait wewenang tetapi pelaku memiliki kesengajaan untuk menguntungkan diri

${ }^{26}$ Yakobus Tefa, Jurnal Mahasiswa S2. Jurnal Mahasiswa S2. 'Korupsi Dalam Pengadaan Barang/jasa Secara Elektronik Corruption in the Electronic Government Procurement. '(2013) 4 (2) Jurnal Nestor Magister Hukum. 
sendiri atau pelaku memang bermaksud untuk menguntungkan diri sendiri secara melawan hukum maka kesalahan adminitrasi tersebut akan dipertanggungjawabkan sesuai dengan hukum pidana sebagai tangung jawab pribadi.

Pertanggungjawaban pidana dari pelaku yang melakukan kesalahan dalam penyusunan HPS dilihat dari sudut pandang Hukum Pidana lebih tepatnya Tindak Pidana Korupsi dapat dilihat dari putusan pengadilan terkait kasus yang berkaitan dengan kesalahan penyusunan HPS yang terindikasi Tindak Pidana Korupsi.

\section{Analisis Perkara Tindak Pidana Korupsi terkait Harga Perkiraan Sendiri (HPS)}

\section{Analisis Putusan Nomor 16/Pid.Sus-TPK/2015/PN.KPG}

Dalam kasus tersebut dapat dilihat bahwa Muhammad Rusdi sebagai PPK yang dalam Peraturan Presiden Nomor 16 Tahun 2018 Tentang Pengadaan Barang/ Jasa Pemerintah memiliki tugas salah satunya untuk menetapkan HPS. Terdakwa Rusdi dalam menyusun HPS melakukan penggelembungan (Mark Up) biaya dapat dilihat dari harga barang/jasa yang tidak realistis sehingga dapat mengakibatkan pembengkakan anggaran. ${ }^{27}$

Dalam putusan tersebut hakim menjatuhkan putusan kepada Terdakwa Rusdi bahwa ia melakukan Tindak Pidana Korupsi sebagaimana dalam dakwaan subsidiar. Berdasarkan dakwaan Subsidiar, Terdakwa Rusdi telah terbukti melakukan kesalahan sebagaimana diatur dalam Pasal Pasal 3 Jo. Pasal 18 Undang-undang Nomor 31 Tahun 1999 tentang Pemberantasan Tindak Pidana Korupsi sebagaimana telah dirubah dengan Undang- undang Nomor 20 Tahun 2001 tentang Perubahan Atas Undang-undang Nomor 31 Tahun 1999 Tentang Pemberantasan Tindak Pidana Korupsi Jo. Pasal 55 ayat (1) ke - 1 KUHPidana.

Pasal 3 Undang-undang Nomor 31 Tahun 1999 tentang Pemberantasan Tindak Pidana Korupsi sebagaimana telah dirubah dengan Undang- undang Nomor 20 Tahun 2001 tentang Perubahan Atas Undang-undang Nomor 31 Tahun 1999

\footnotetext{
${ }^{27}$ Amiruddin, Korupsi Dalam Pengadaan Barang dan Jasa (Genta Publishing 2010).[73].
} 
Tentang Pemberantasan Tindak Pidana Korupsi berbunyi :

"Setiap orang yang dengan tujuan menguntungkan diri sendiri atau orang lain atau suatu korporasi, menyalahgunakan kewenangan, kesempatan, atau sarana yang ada padanya karena jabatan atau kedudukan atau sarana yang ada padanya karena jabatan atau kedudukan yang dapat merugikan keuangan negara atau perekonomian negara, dipidana dengan pidana penjara seumur hidup atau pidana penjara paling singkat 1 (satu) tahun dan paling lama 20 (dua puluh) tahun dan atau denda paling sedikit Rp. 50.000 .000 (lima puluh juta rupiah) dan paling banyak Rp. 1.000.000.000,00 (satu miliar rupiah)".

Tindakan yang dilakukan oleh Terdakwa Rusdi diindikasikan terjadi Tindak Pidana Korupsi berdasarkan Pasal 3 Undang-undang Nomor 31 Tahun 1999 tentang Pemberantasan Tindak Pidana Korupsi sebagaimana telah dirubah dengan Undangundang Nomor 20 Tahun 2001 tentang Perubahan Atas Undang-undang Nomor 31 Tahun 1999 Tentang Pemberantasan Tindak Pidana Korupsi karena ia sebagai subjek hukum manusia yang berprofesi sebagai Pegawai Negeri yang bekerja di Kantor Badan Kesatuan Bangsa Politik dan Perlindungan Masyarakat Kabupaten Alor dan dalam kegiatan Pengadaan PDL Linmas Terdakwa ditunjuk sebagai PPK dengan tugas dan kewenangan yang melekat padanya. Terdakwa melakukan penyalahgunaan kewenangan, kesempatan atau sarana yang ada pada Jabatannya sebagai PPK di Pengadaan PDL Linmas, hal ini dapat dilihat dari pada saat Terdakwa Rusdi menyusun harga HPS dengan penentuan harga yang jauh lebih tinggi.

Harga dasar PDL melalui survey ke perusahaan garment di malang yang didapatkan untuk menyusun HPS adalah sebesar Rp. 480.000,- / 1 set. Dari harga dasar tersebut terdakwa menentukan HPS yang belum termasuk perhitugan biaya lain hingga mencapai harga ) Rp. 805.275,- / 1 set. Sedangkan jumlah HPS yang ditetapkan setelah ditambahkan komponen biaya keuntungan, PPN, Biaya lain-lain adalah sebesar Rp. 862.500,- / 1 set. Perbedaan rentang harga yang ditentukan oleh terdakwa Rusdi dibandingkan dengan harga dasar cukup jauh. Penentuan HPS yang terlalu tinggi dapat diindikasikan bahwa terhadap HPS tersebut telah dilakukan penggelembungan harga (Mark $U p)$.

Selain itu, dalam rincian kompoen biaya penyusunan HPS disebutkan bahwa ada biaya yang ditambahkan untuk biaya inspeksi awal PPK ke pabrik / survey 
harga oleh PPK. Sedangkan harga dasar tersebut didapatkan oleh terdakwa via pesan elektronik email, sehingga tidak ada biaya yang dikeluarkan untuk melakukan suvey langsung ke lokasi perusahaan garment di malang tersebut. Terdakwa telah memenuhi keseluruhan unsur Pasal 3 UU Tindak Pidana Korupsi.

Sehingga terdakwa memenuhi unsur dengan tujuan menguntungkan diri sendiri atau orang lain atau suatu korporasi, yang dimaksud menguntungkan dalam Pasal ini adalah tindakan yang bertujuan untuk mendapatkan untung atau profit terlepas dari pendapatan yang diperolehnya untuk diri sendiri atau orang lain. ${ }^{28}$ Bahwa terdakwa melakukan Mark $U p$ terhadap HPS pengadaan PDL Linmas dengan cara menghitung biaya tak terduga dan biaya lain-lain dalam penyusunan nilai HPS agar ada uang lebih untuk dapat disalahgunakan atau diambil untuk diri Terdakwa Sendiri. Oleh karena itu unsur dengan tujuan menguntungkan diri sendiri atau orang lain atau suatu korporasi terpenuhi.

Pada saat terdakwa melakukan Mark Up HPS Pengadaan PDL Linmas dapat mengakibatkan pembengkakan anggaran yang dikeluarkan untuk membeli PDL tersebut karena harga penawaaran yang diajukan oleh penyedia juga akan menyesuaikan HPS. Oleh karena itu tindakan terdakwa untuk melakukan penggelembungan HPS memungkinkan timbulnya kerugian keuangan Negara, jadi unsur dapat merugikan keuangan negara atau perekonomian Negara telah terpenuhi

Penyusunan HPS diperoleh dengan perhitungan harga dasar ditambah keuntungan 15\%, Pajak 11,5\%, ekspedisi, PPh 1,5\% dan biaya tidak terduga antara lain biaya inflasi. Selain itu terdakwa juga menambahkan komponen biaya mobilisasi antar jemput PDL Linmas sementara penyerahan PDL Linmas dilakukan di kantor Badan Kesbagpol Linmas Kabupaten Alor. Oleh karena beberapa komponen biaya tersebut tidak sesuai dengan ketentuan dalam Peraturan Presiden Nomor 54 Tahun 2010 Tentang Pengadaan Barang/Jasa Pemerintah maka terpenuhilah unsurunsur dalam Pasal 3 UU Tindak Pidana Korupsi. Sehingga upaya terdakwa untuk melakukan penggelembungan harga / Mark Up dalam penyusunan HPS Pengadaan

\footnotetext{
${ }^{28}$ R. Wiyono, Pembahasan Undang-undang Pemberantasan Tindak Pidana Korupsi (Sinar Grafika 2009).[46].
} 
PDL Linmas adalah benar.

2. Analisis Putusan Nomor 1047/ PID.B/2010/PN.Smda.

Karena jabatan yang dimiliki oleh para terdakwa maka mengakibatkan timbulnya wewenang dalam adanya pengadaaan CT Scan. Salah satu wewenangnya adalah menyusun dan menetapkan HPS, namun Terdakwa hanya menuliskan HPS di selembar kertas dan tidak dilakukan penetapan. Pengelola pengadaan dalam menyusun HPS dilakukan dengan cara mencari rata-rata dari 3 perusahaan yang datang untuk melakukan presentasi setelah diundang oleh pihak RSUD A.Wahab, 3 diantaranya yaitu PT Siemens, PT Philips dan PT Toshiba. Dari ketiga informasi harga tersebut pengelola pengadaan CT Scan menentukan nilai HPS untuk pengadaan tersebut adala senilai Rp 20.689.400.000,- itu sudah termasuk biaya PPN sampai dengan barang datang dan sudah ditambah dengan biaya peralatan tambahan sejumlah Rp 357.500.000,-

Namun pada saat pengadaan telah dilaksanakan ditemukan hasil audit yang menyatakan adanya kemahalan harga. Auditor dalam menentukan kemahalan harga tersebut melihat bahwa kontrak pengadaan CT Scan antara PT Poros Timur dan RSUD A.Wahab adalah sejumlah Rp.20.379.700.000,- sedangkan PT Poros mengambil atau memesan Alat CT Scan dari PT Siemens dengan harga Rp 13.750.000.000,- sehingga ditemukan ada selisih sekitar Rp.7.000.000.000,- lebih. Perbedaan inilah yang mengakibatkan auditor menilai adanya kemahalan karena auditor melihat patokan harganya dari harga CT Scan yang dibeli PT Poros dari PT Siemens. Oleh karena itu unsur yang dapat merugikan keuangan Negara atau perekonomian Negara terpenuhi.

Pada saat dilakukan audit terhadap pengadaan CT Scan, ditemukan adanya kemahalan harga yang diindikasikan Tindak Pidana Korupsi. Hasil audit yang menyatakan adanya kemahalan harga tersebut disebabkan karena adanya perbedaan faktor akses informasi antara auditor dan pihak pengelola pengadaan yang melakukan penyusunan HPS. Apabila barang/jasa sumber informasi yang digunakan untuk menyusun HPS berasal dari E-Catalog-Inaproc, E Purchasing, atau informasi harga satuan resmi oleh BPS, Badan/Instansi lainnya yang telah ditetapkan oleh 
pihak pemerintah maka kemungkinan adanya indikasi Tindak Pidana Korupsi akan lebih kecil dikarenakan pihak auditor dan/atau penegak hukum dengan PA/KPA, dan PPK sumber informasi harga dari pihak tersebut berasal dari sumber yang sama.

Apabila sumber informasi harga untuk menyusun HPS didapatkan dari barang/jasa yang dikeluarkan oleh pabrik atau distributor tunggal atau biaya dari kontrak sejenis sebelumnua maka akan terjadi ketidakseimbangan akses informasi harga antara auditor dan/atau penegak hukum dengan PA/KPA dan PPK. Karena auditor atau penegak hukum akan lebih mudah mendapatkan informasi harga karena diminta sebagai kepentingan penyidikan atau penyelidikan. Sedangkan apabila informasi harga diminta untuk kepentingan penyusunan HPS maka informasi harga tersebut akan sulit untuk diperoleh karena pihak yang diminta informasi hargadari kontrak sejenis sebelumnya akan khawatir apabila informasi harga yang diberikan tersebut lebih rendah dibandingkan dengan pihak yang meminta data informasi harga dari kontrak sebelumnya sehingga diindikasikan adanya unsur Mark Up.

Dengan ditetapkannya PT Poros sebagai Pemenang pengadaan maka PT mengadakan kontrak jual beli CT Scan dengan PT Siemens dengan kontrak sebesar 13.750.000.000,- agar PT Poros dapat memenuhi barang untuk Pengadaan CT Scan dengan RSUD A. Wahab. Namun setelah dilakukan audit ditemukan bahwa harga wajar kontrak pengadaan antara PT Poros dan RSUD A.Wahab adalah sebesar Rp 16.680.749.002,50 sudah termasuk PPN dan keuntungan sehingga ditemukan selisih.

Berdasarkan penjelasan diatas, dilihat dari amar dan pertimbangann majelis hakim pada putusan ini memutuskan untuk mengadili Terdakwa karena tindakannya terindikasi tindak pidana korupsi. Dari kasus tersebut ditemukan adanya selisih dikarenakan pedoman harga pada saat melakukan audit berbeda dengan pedoman pada saat PPK menentukan Harga untuk menyusun HPS, dan dalam menyusun HPS PPK tersebut tidak ada niat untuk menguntungkan diri sendiri dengan cara menyalahgunakan wewenangnya dalam menyusun HPS maka seharusnya perbedaan pedoman harga pada saat melakukan audit berbeda dengan pedoman pada saat PPK menentukan Harga untuk menyusun HPS tidak menjadi alasan untuk dijatuhkannya pidana kepada pelaku. Sebab pedoman untuk melakukan audit 
tersebut sudah berbeda dengan pedoman dalam menyusun HPS, sehingga hasil auditnya pasti berbeda dengan HPS yang ditentukan. Akibatnya dari perbedaan tersebut ditemukanlah kemahalan harga dalam HPS Pengadaan CT Scan tersebut.

Selain itu, berdasarkan analisis diatas, Terdakwa memenangkan PT Poros walaupun dokumen penawaran yang diajukan oleh PT Poros tidak memenuhi syarat seperti dokumen penawaran PT. Poros Timur Utama tidak di sertai dengan Surat Dukungan dari Bank, namun hanya melampirkan Dokumen Surat Bank Mandiri Cabang Samarinda yang menyatakan bahwa Bank Mandiri akan menilai dan mempertimbangkan untuk mendukung PT. Poros Timur Utama bukan sebagai komitmen Bank untuk membiayai kegiatan dan diberikan hanya dalam rangka memenuhi persyaratan prakualifikasi kegiatan pengadaan CT Scan. Hal ini bertentangan dengan ketentuan lampiran I BAB II a.I.b.I Persyaratan Kualifikasi Penyedia Barang/Jasa huruf L Keppres No. 80 tahun 2003 yang pada pokoknya menyatakan bahwa penyedia memiliki surat keterangan dukungan dari bank pemerintah/swasta untuk mengikuti Pengadaan Barang/Jasa sekurangkurangnya $10 \%$ dari nilai proyek sehingga PT. Poros Timur Utama tidak dapat dijadikan pemenang lelang. Dan ditemukan pula bahwa Sdr. Abdul Jamal Balfas selaku pemilik dari PT Poros mempunyai kepemilikan 2 (dua) peruisahaan yang mengajukan penawaran yaitu PT. Poros Timur Utama dan PT. Niaga Citra Pandurata Sehingga hal ini menguntungkan PT Poros sebagai pemenang pengadaan. Hal ini bertentangan dengan ketentuan angka 5.1 dan bab I A umum dokumen Pelelangan yang menyatakan bahwa setiap peserta lelang atas nama sendiri atau sebagai anggota kemitraan hanya boleh menyerahkan satu penawaran untuk satu paket pelelangan pekerjaan. Dan peserta lelang yang menyerahkan lebih dari satu penawaran untuk satu paket pelelangan pekerjaan, selain penawaran alternatif akan digugurkan.

\section{Analisis Putusan Nomor 11/Pid.Sus-TPK/2016/PN. Tpg}

Permasalahan dalam putusan ini adalah terkait adanya persekongkolan yang mengakibatkan adanya persaingan usaha tidak sehat yang mana atas persekongkolan tersebut, pihak Pengelola pengadaan seperti Pokja dan PPK tetap meloloskan dokumen penawaran yang terindikasi adanya persekongkolan. Selain 
itu permasalahan dalam penyusunan HPS yang disusun tidak sesuai dengan dengan Perpres No. 70 Tahun 2012, tentang Perubahan Kedua Atas Peraturan Presiden Nomor 54 Tahun 2010 tentang Pengadaan Barang/Jasa Pemerintah.

Terkait masalah persekongkolan, Persekongkolan dapat terjadi diantara pelaku usaha dengan pengelola pengadaan maupun terjadi diantara pelaku usaha dengan pelaku usaha lain. Persekongkokolan antara pelaku usaha dengan pengelola pengadaan dapat dilakukan dengan cara membuat dokumen pengadaan seperti HPS dan spesifikasi teknis yang diarahkan untuk pelaku usaha tertentu sehingga mengakibatkan kemungkinan pengadaan dimenangkan oleh pelaku usaha tertentu lebih besar. Sedangkan persekongkolan antara pelaku usaha dengan pelaku usaha lain dapat dilakukan dengan cara menciptakan persaingan semu diantara pelaku usaha sehingga mengakibatkan pemenang untuk suatu pengadaan sudah ditentukan lebih dulu oleh pelaku usaha.

Perusahaan yang mengajukan dokumen penawaran berasal dari 3 perusahaan yaitu PT Cakrayudha Persada, PT Raja Prakasa dan PT Daya Mandiri Sentosa padahal dari dokumen penawaran ketiga perusahaan tersebut diindikasikan adanya persekongkolan untuk memenangkan PT Cakrayudha Persada. Hal ini dilihat dari dokumen penawaran antara PT Cakrayudha Persada dan PT Raja Prakasa terdapat kesamaan susunan, format dan kesamaan dalam kesalahan pengetikan. Indikasi yang lain dilihat dari dokumen jaminan penawaran dari PT Cakrayudha Persada dan PT Raja Prakasa dikeluarkan oleh Bank BNI Cabang Utama Bandung, sedangkan PT Cakrayudha Persada berkedudukan di bandung dan PT Raja Prakasa berkedudukan di Jakarta selatan. Sehingga tindakan berupa persekongkolan terbukti menguntungkan salah satu pihak saja.

Selain permasalahan terkait adanya persekongkolan, terdakwa dijatuhi pidana dikarenakan melakukan tindak pidana korupsi dilihat dari kesalahan tindakan terdakwa dalam menyusun HPS. Salah satu tugas dari PPK adalah menyusun HPS dalam tahap persiapan. Dalam menyusun HPS terdakwa berpedoman pada price list dari perusahaan berupa jenis barang,spesifikasi dan harga. terdakwa tidak melakukan klarifikasi mengenai komponen biaya lain seperti biaya pengiriman, kurs 
valuta asing, PPN, dan keuntungan, kurang lengkapnya informasi yang di dapatkan untuk menyusun HPS dapat mengakibatkan pembengkakan biaya anggaran dalam pelaksanaan pengadaan.

Dengan ditentukannya nilai sebesar $\mathrm{Rp} 3.440 .959 .400$,- sebagai HPS, perusahaan yang memenangkan tender yaitu PT Cakrayudha Persada mengajukan penawaran dengan nilai Rp 3.291.097.480,- yang kemudian nilai penawaran tersebut menjadi nilai kontrak pengadaan alat dan bahan kimia laboratorium. Namun pada saat pembayaran, jumlah yang dibayarkan ke rekanan sejumlah Rp 2.530.326.480,berbeda dengan nilai kontrak yang telah ditentukan. Sehingga terdapat sisa dana sebesar Rp.760.771.000,-.

Dari penjelasan diatas, Persekongkolan yang terjadi ini melanggar ketentuan Pasal 83 ayat (1) huruf e Peraturan Presiden Nomor 70 Tahun 2012 tentang Perubahan Kedua Atas Peraturan Presiden Nomor 54 Tahun 2010 Tentang Pengadaan Barang/Jasa Pemerintah dan penjelasannya, bahwa PA/KPA dapat menyatakan suatu pelelangan menjadi gagal apabila PPK tidak bersedia menandatangani SPPBJ karena proses pelelangan tidak sesuai dengan Peraturan Presiden Nomor 70 Tahun 2012 . Seharusnya apabila terjadi indikasi persaingan tidak sehat seperti persekongkolan maka Pokja 3 ULP dan PPK menghentikan proses lelang tersebut setelah berkonsultasi dengan Pengguna Anggaran (PA) atau Kuasa Pengguna Anggaran (KPA) atau melakukan evaluasi ulang. Namun hal tersebut tidak dilakukan oleh Pokja maupun Terdakwa, Terdakwa malah menetapkan PT. Cakrayudha Persada sebagai pemenang lelang dengan menandatangani SPPBJ.

Dan berdasarkan penjelasan terkait penyusunan HPS, kesalahan penyusunan HPS terjadi dikarenakan ketidakcermatan terdakwa dalam menyusun HPS yang hanya berpedoman hanya berdasarkan catalog dan price list dari distributor tanpa mempertimbangkan untuk menambahkan komponen harga lain dan tanpa melakukan klarifikasi masalah harga, ketersediaan stok barang, discount, biaya pengiriman, kurs valuta asing dan lainnya yang berkaitan dari perusahaan atau distributor yang mengajukan penawaran. Akibatnya HPS 
yang disusun mengakibatkan adanya pemborosan keuangan Negara Sehingga bertentangan dengan psal 66 ayat (8) Perpres No. 70 Tahun 2012, tentang Perubahan Kedua Atas Peraturan Presiden Nomor 54 Tahun 2010 tentang Pengadaan Barang/Jasa Pemerintah.

\section{Kesimpulan}

Dalam melakukan penyusunan HPS dapat terjadi kesalahan yang berimplikasi Tindak Pidana Korupsi dan kesalahan yang tidak berimplikasi Tindak Pidana Korupsi. Kesalahan penyusunan HPS yang tidak berimplikasi pada Tindak Pidana Korupsi yaitu adanya kesalahan secara prosedural, wewenang dan subtansi yang dalam tindakannya tidak ada kesengajaan untuk memperkaya diri sediri ataupu orang lain maka atas tindakannya tersebut akan mengakibatkan adanya tanggung jawab jabatan. Kesalahan administrasi tidak dapat dipertanggungjawabkan secara pidana. Tetapi apabila dalam pelaksanaanya diketahui bahwa kesalahan administrasi yang dilakukan tersebut menimbulkan kerugian keuangan negara karena pejabat tersebut memiliki niat atau kesengajaan untuk memperkaya diri sendiri dengan menyalahgunakan wewenang, kesempatan maupun jabatan maka kesalahan administrasi tersebut merupakan penyebab terjadinya tindak pidana korupsi sehingga dapat dipertangungjawabkan secara pidana.

Kesalahan dalam penyusunan HPS yang berakibat tindak pidana melahirkan Pertanggungjawaban pidana. Salah satu pola kesalahan dalam penyusunan HPS dapat terdeteksi dari unit-price yang tidak realistis dan pembengkakan jumlah APBN/APBD. Atas kesalahan tersebut maka pengelola pengadaan dengan jabatan apapun yang sengaja melakukan tindakan menyalahi peraturan perundang-undangan terkait Pengadaan Barang/Jasa sehingga mengakibatkan adanya kesalahan dalam penyusunan Harga Perkiraan Sendiri (HPS) dapat dijatuhkan tindak pidana dengan memperhatikan kemampuan bertanggungjawab pihak tersebut. 


\section{Daftar Bacaan}

\section{Buku}

Amiruddin, Korupsi Dalam Pengadaan Barang dan Jasa (Genta Publishing 2010).

Amir Ilyas, Asas-Asas Hukum Pidana Memahami Tindak Pidana Dan Pertanggungjawaban Pidana Sebagai Syarat Pemidanaan (Rangkang Education Yogyakarta \& PuKAP-Indonesia 2012).

Mudjisantosa, Catatan Aspek Hukum Pengadaan dan Kerugian Negara (CV Primaprint 2014).

Moeljatno, Asas-asas Hukum Pidana (Rineka Cipta 2008).

Philipus M. Hadjon, dkk, Hukum Administrasi dan Tindak Pidana Korupsi (Gadjah Mada University Press 2012).

R. Wiyono, Pembahasan Undang-undang Pemberantasan Tindak Pidana Korupsi (Sinar Grafika 2009).

Samsul Ramli, Bacaan Wajib Mengatasi Aneka Masalah Teknis Pengadaan Barang dan Jasa (Transmedia pustaka 2014).

\section{Jurnal dan Artikel}

Alfian Malik, 'Analisa Disparitas Harga Penawaran Terhadap Harga Perkiraan Sendiri Pada Pemilihan Penyedia Jasa Pekerjaan Jalan Dan Jembatan'(2013) 2 (5) Jurnal Aptek.

Maslani Dan Siswanto, 'Audit Pengadaan Barang Jasa Mengenal Risiko Penyimpangan Untuk Pencegahan' (2011) 1 Jurnal Pengadaan Senarai Pengadaan Barang / Jasa Pemerintah.

Nur Sayidah, 'Solusi Moral Dan Spiritual Atas Masalah Moral Hazard' (2017) Jurnal Ilmiah Akuntansi Dan Humanika

Randy Kristovandy Tamesia, 'Studi Efektivitas Pengadaan Barang dan Jasa Pemerintah Secara Tradisional dan Elektronik' (2015) 2 (12) Jurnal Teknik Sipil.

Salman Luthan, Luthan, Salman, 'Asas Dan Kriteria Kriminalisasi' (2006) 1 (16) Jurnal Hukum.

Senator Nur Bahagia, 'Sistem pengadaan publik dan cakupannya' (2011) 1 (1) 
Jurnal Pengadaan Senarai Pengadaan Barang / Jasa Pemerintah.

Tommy J. Bassang, 'Pertanggungjawaban Pelaku Tindak Pidana Deelneming' (2015) 5 (IV) Lex Crimen.

Yakobus Tefa, Jurnal Mahasiswa S2. Jurnal Mahasiswa S2. 'Korupsi Dalam Pengadaan Barang/jasa Secara Elektronik Corruption in the Electronic Government Procurement. '(2013) 4 (2) Jurnal Nestor Magister Hukum.

\section{Skripsi/Tesis/Desertasi}

A Edwin Parawangsyah, Analisis Hukum Tindak Pidana Korupsi Pada Bidang Pengadaan Barang/Jasa Konstruksi (Studi Putusan Nomor 74/Pid.Sus/2014/ Pn.Mks), Fakultas Hukum Universitas Hassanudin, Makassar, 2017.

Dwi Sukarmei, Pengaruh Metode Evaluasi Penawaran Pengadaan Barang/Jasa Pemerintah Terhadap Hasil Pekerjaan Dengan Pendekatan Analytical Hierarchy Process ( Studi Kasus Di Pemerintah Kabupaten Temanggung ), Tesis , Program Magister Teknik Sipil Universitas Diponegoro, 2011.

Fitrahwaty Porwilah Syarif, Tinjauan Yurudis Kealpaan Seseorang Yang Menyebabkan Matinya Orang Lain Dalam Kecelakaan Lalu Lintas Di Polres Maros (Studi Kasus No. 136/Pid.B/2012/Pn.Mrs), Skripsi, Program Studi Ilmu Hukum Universitas Hasanuddin, Makkasar, 2013.

\section{Kamus}

Black, Henry Campbell. 1995. Black's Law Dictionary. U.S: West Publishing. Co.

\section{Laman}

Ambranie Nadia Kemala Movanita, "Ini celah kecurangan pengadaan barang dan jasa yang bertonse korupsi”, Kompas.com (online), 28 September 2017. https://nasional.kompas.com/read/2017/09/28/19204361/ini-celahkecurangan-pengadaan-barang-dan-jasa-yang-berpotensi-korupsi?page=all

Bagian Pengadaan Barang/Jasa, "Daftar Isian Pelaksanaan Anggaran (DIPA): Jenis, Format dan Tata Cara Revisi DIPA", https://bulelengkab.go.id, 31 Oktober 2018, dikunjungi pada tanggal 16 Oktober 2019 
--halaman ini sengaja dibiarkan kosong-- 